\title{
Comparison among the Toxicity of Thymol and Certain Pesticides on Adults Survival and Egg Hatchability of the Glassy Clover Snail Monacha cartusiana (MÜLLER) \\ Mona A. Ali \\ Plant Protection Research Institute, Agric. Res. Center, Dokki, Giza, Egypt
}

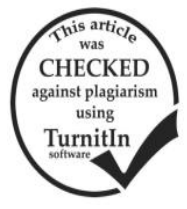

\section{ABSTRACT}

Land gastropods have become important economic pests attacking various vegetation in Egypt. This study aimed to determine the molluscicidal activity of the monoterpenoids compound, Thymol and three pesticides (Neomyl, Kafrothrin and Round up) against adult's survival and egg hatchability of the glassy clover snail Monacha cartusiana under laboratory and field conditions. Poisonous baits technique gave better results than did leaf dipping technique. The obtained results indicated that Neomyl was the most effective one followed by Thymol and Kafrothrin then Round up which had the lowest affect against the adult of $M$. cartusiana with LC50 0.79, 1.78, 3.62 and 0.49 ppm respectively. Also, Neomyl was the most effective one on the incubation period of eggs of M. cartusiana ( 25 days in average) followed by Thymol ( 23.5 days in average), Kafrothrin ( 23 days in average) and Round up (22 days in average). Similar trend was noticed with mean egg hatchability with values of 1.0, 1.8, 3.0 and 4.4, respectively. In field experiment represented using poisonous baits of such compounds Neomyl $(72.61 \%)$ gave the highest reduction percentage in Egyptian clover fields naturally infested with $M$. cartusiana followed by Thymol (55.82\%) and Kafrothrin $(50.03 \%)$ then Round up (17.20\%). The obtained results proved that the use of Thymol in controlling harmful land snail would achieve effectiveness comparable to synthetic molluscicides.

Keywords: Land snails, Monacha cartusiana, Thymol, pesticides.

\section{INTRODUCTION}

Terrestrial molluscs are considered a significant threat to sustainable agriculture in many parts of the world (Barker, 2002). They are major pests of a wide range of agricultural and horticultural crops in temperate and humid habitats worldwide (Speiser and Kistler, 2002). Economic damage caused by these molluses is due to feeding and contamination with their bodies, feces or slime, leading to deterioration of the product quality, in addition to the financial loss (Iglesias et al., 2003). The glassy clover snail, Monacha cartusiana (Müller) causes damage to vegetables and field crops (El-Deeb et al., 2003).

Molluscicides of plant origin are natural products and are ecologically preferable than synthetic ones (Kumar et al., 2012). Plant - derived products have been suggested as alternatives for pest control. Particularly, monoterpenoids have been recently used for the purpose of pest control as insecticides (Rice and Coats 1994) and molluscicides (Powell and Bowen 1996). Thymol is a monoterpenoid plant substance obtained from the essential oil of Laminacea species. It is a part of naturally occurring class of compounds known as biocides. It acts as a bactericide, fungicide and has antimicrobial activity because of its phenolic structure (Wicht et al., 2004).

Therefore, this study was carried out to compare the effect of Thymol as active ingredient with certain pesticides on adult's mortality and egg hatchability of the glassy clover snail, Monacha cartusiana under laboratory and field conditions.

\section{MATERIALS AND METHODS}

\section{Experimental snails:}

Adults of the land snail Monacha cartusiana were handily collected from infested fields at Al Khayariyah village, Mansoura district, Dakahlia Governorate. The obtained snails were transferred to the laboratory and then kept in plastic containers filled with moist sterilized sandy loamy soil at $25 \mathrm{C}^{\circ} \pm 2 \mathrm{C}^{\circ}$ and 75
$\% \pm 5 \%$ soil moisture. Snails were fed on fresh leaves of lettuce (Lactuca sativa L.) for 14 days to be laboratory acclimatized. Dead and unhealthy snails were removed and only healthy ones were used in the experiments.

Tested Compounds:

1-Thymol is monoterpenoid compound and white crystalline substance of a pleasant aromatic odor.

Chemical name: 5-methyl-2-(1-methyl-ethyl) phenol.

The structure formula: $\left(\mathrm{C}_{10} \mathrm{H}_{14} \mathrm{O}\right)$.

Thymol was obtained from El- Gomhoria company- Mansoura with purity $99.5 \%$.<smiles>C=C(C)/C=C\C(=C/O)C(C)C</smiles>

\section{Chemical structure of Thymol}

2- Deltamethrin:(Kafrothrin $2.5 \%$ EC)Pyrethroid ester insecticide.

Chemical name:[(S)-cvano-(3-phenoxvphenvl)methvl] (1R,3R)-3-(2,2-dibromoethenyl)-2,2-dimethylcyclopropane -1-carboxylate

The structure formula: $\left(\mathrm{C}_{22} \mathrm{H}_{19} \mathrm{Br}_{2} \mathrm{NO}_{3}\right)$<smiles>CC1(C)C(C(=O)OC(C#N)c2cccc(Oc3ccccc3)c2)[C@H]1C=C(Br)Br</smiles>

Chemical structure of Deltamethrin

3-Glyphosate:(Round up 48 \% SL)Organophosphorous herbicide

Chemical name: (N- (Phosphonomethyl) glycine.

The structure formula: $\left(\mathrm{C}_{3} \mathrm{H}_{8} \mathrm{NO}_{5} \mathrm{P}\right)$. 
<smiles>O=C(O)CNCP(=O)(O)O</smiles>

Chemical structure of Glyphosate

4-Methomyl:(Neomyl $20 \%$ SL) Carbamate insecticide. Chemical name: S-methyl N (methylcarbamoyloxy) thioacetimidate.

The structure formula: $\left(\mathrm{C}_{5} \mathrm{H}_{10} \mathrm{~N}_{2} \mathrm{O}_{2} \mathrm{~S}\right)$.<smiles>CNC(=O)O/N=C(\C)SC</smiles><smiles>CNC(=O)O/N=C(/C)SC</smiles>

Chemical structure of Methomyl

Laboratory experiments:-

1- Leaf- dipping technique:

Four concentrations of Thymol, Kafrothrin, Round up and Neomyl were used. For each concentration fresh lettuce leaves were dipped for one minute and left for dryness (Ghamry, 1994). The treated leaves were placed inside plastic boxes filled with moist sterilized sandy loamy soil. Ten adult snails of $M$. cartusiana were placed into each box. Each box was covered with muslin cloth fixed with rubber bands to prevent snails from escaping. Each concentration had three replicates and untreated lettuce disks were used as a control treatment. Mortality percentage was recorded after 1, 3, 5 and 7 days post treatments.

\section{2- Poisonous baits technique:}

Three concentrations (1, 2 and 4\%) were prepared for each compound. Baits were prepared by incorporating the appropriate amount of each compound and added 5 parts of sugar cane syrup then completed with wheat bran to give 100 parts from baits (El-Okda, 1981). Control treatment was prepared using bran bait free from any compound. Five grams of each poison bait were spread into each box filled with moist sterilized sandy loamy soil. Ten adults of $M$. cartusiana snails were introduced and then tightly covered with muslin clothes netting and secured with rubber band to prevent snail from escaping. All tested compounds and control were replicated three times. The tested snails were examined daily, where the dead individuals were counted and removed. Mortality percentage was recorded after 1, 3, 5, 7 days post treatment.

Toxicity of the tested compounds:

1- Mortality percentages were corrected according to Abbott's formula (Abbott, 1925). LC $_{50}$ values were determined using probit analysis statistical method of Finney (1971).

2- Toxicity index of the tested compounds was determined according to Sun equation (Sun, 1950) as follows:

Toxicity index $\left(\mathrm{LC}_{50}\right)=\frac{\mathrm{LC}_{50} \text { of the most effective compound }}{\mathrm{LC}_{50} \text { of the least effective compound }} \mathrm{X} 100$
Effect of Thymol and three pesticides on incubation period and hatchability percentages of Monacha cartusiana:

Adult land snail, $M$. cartusiana was put in cultural box. The soil was examined daily to search new clutches of eggs. Newly deposited clutches were collected by a fine hair brush. The eggs were divided into batches of 20 eggs. Each batch of eggs (up to $24 \mathrm{~h}$ old) was placed in a culture dish containing $5 \mathrm{~g}$ of sterile moist soil. One $\mathrm{ml}$ of each compound solution $\left(\mathrm{LC}_{50}\right)$ was topically applied directly on egg batches. All tested compounds and control groups were replicated five times and distilled water were used as a control treatment. The eggs were examined daily for a period of one month to record the date of hatching and incubation period. Percentage of egg hatchability was calculated and recorded.

\section{Field experiment:}

The tested compounds were applied in a field cultivated with Egyptian clover highly infested with $M$. cartusiana at Al Khayariyah village, Mansoura district, Dakahlia Governorate. The tested compounds were applied as poisonous wheat bran baits at the concentration of $2 \%$ for each compound. The applied concentration was prepared by incorporation of the tested toxicant into bait formulation consisted of sugar cane syrup and wheat bran ( 2 parts toxicant +5 parts of sugar cane syrup +93 parts of wheat bran). Each treatment was replicated three times and the control treatment was designed by the same manner without any toxicant. Baits were offered on plastic pieces each one about $100 \mathrm{gm}$. Alive snail was recorded in check and treatment areas before application and after 1, 3, 7, 14 and 21 days until the end of the experiment. Reduction percentages of $M$. cartusiana were calculated according the formula of Henderson and Tilton (1955) as follow:

$$
\% \text { Reduction }=100[1-\text { t } 2 \text { r1/t1r2 }]
$$

where:

$\mathrm{r} 1=$ number of alive snails before treatment in untreated plots.

$\mathrm{r} 2=$ number of alive snails after treatment in untreated plots.

$\mathrm{t} 1=$ number of alive snails before treatment in treated plots.

$\mathrm{t} 2=$ number of alive snails after treatment in treated plots.

\section{RESULTS AND DISCUSSION}

1-Comparison among the toxicity of Thymol and certain pesticides towards Monacha cartusiana adult snail using leaf dipping technique under laboratory conditions:

Data presented in Table (1) indicated that Neomyl caused high mortality percentage for $M$. cartusiana adult snails followed by Kafrothrin and Thymol then Round up. However, the toxicity of such compounds was increased with increasing the concentration. At higher concentration, the greatest percentage in adult's mortality was recorded one day post treatment.

As shown in Table (2) and Fig (1) $\mathrm{LC}_{50}$ and $\mathrm{LC}_{90}$ values were $12360.0,1095.9,17688.7$ and $834.9 \mathrm{ppm}$ and 54403.1, 8232.7, 49621.1 and $7388.8 \mathrm{ppm}$ for Thymol, Kafrothrin, Round up and Neomyl, respectively. 
Table 1. Mortality percentages of Monacha cartusiana adult snails after the exposure to different concentrations of Thymol and three pesticides using leaf dipping technique under laboratory conditions.

\begin{tabular}{lcccccc}
\hline Treatments & Conc. & \multicolumn{2}{c}{ Mortality after treatments \% } & \multicolumn{2}{c}{ Total Mortality } \\
& (ppm) & One day & Three days & Five days & Seven days & \% \\
\hline \multirow{4}{*}{ Thymol } & 5000 & 0.00 & 6.67 & 3.33 & 16.67 & 26.67 \\
& 10000 & 10.00 & 0.00 & 10.00 & 13.33 & 33.33 \\
& 15000 & 23.33 & 10.00 & 6.67 & 13.33 & 53.33 \\
\multirow{4}{*}{ Kafrothrin } & 20000 & 26.66 & 26.66 & 0.00 & 20.00 & 73.32 \\
& 500 & 6.66 & 10.00 & 3.33 & 6.66 & 26.65 \\
& 1000 & 13.33 & 26.66 & 6.67 & 6.67 & 53.33 \\
Round up & 2000 & 23.33 & 30.00 & 0.00 & 13.33 & 66.66 \\
& 4000 & 36.66 & 20.00 & 20.00 & 0.00 & 76.66 \\
& 10000 & 0.00 & 3.33 & 13.33 & 6.66 & 23.32 \\
Neomyl & 12000 & 0.00 & 10.00 & 10.00 & 13.33 & 33.33 \\
& 15000 & 6.66 & 13.33 & 3.33 & 16.66 & 39.98 \\
& 20000 & 20.00 & 16.67 & 10.00 & 10.00 & 56.67 \\
& 1000 & 23.33 & 16.66 & 10.00 & 6.66 & 56.65 \\
& 2000 & 30.00 & 26.66 & 3.33 & 6.67 & 66.66 \\
\end{tabular}

Table 2. Molluscicidal activity $\left(\mathrm{LC}_{50}\right.$ and $\left.\mathrm{LC}_{90}\right)$ of $\mathrm{Thymol}$ and three pesticides against glass clover snail, Monacha cartusiana using leaf dipping technique under laboratory conditions.

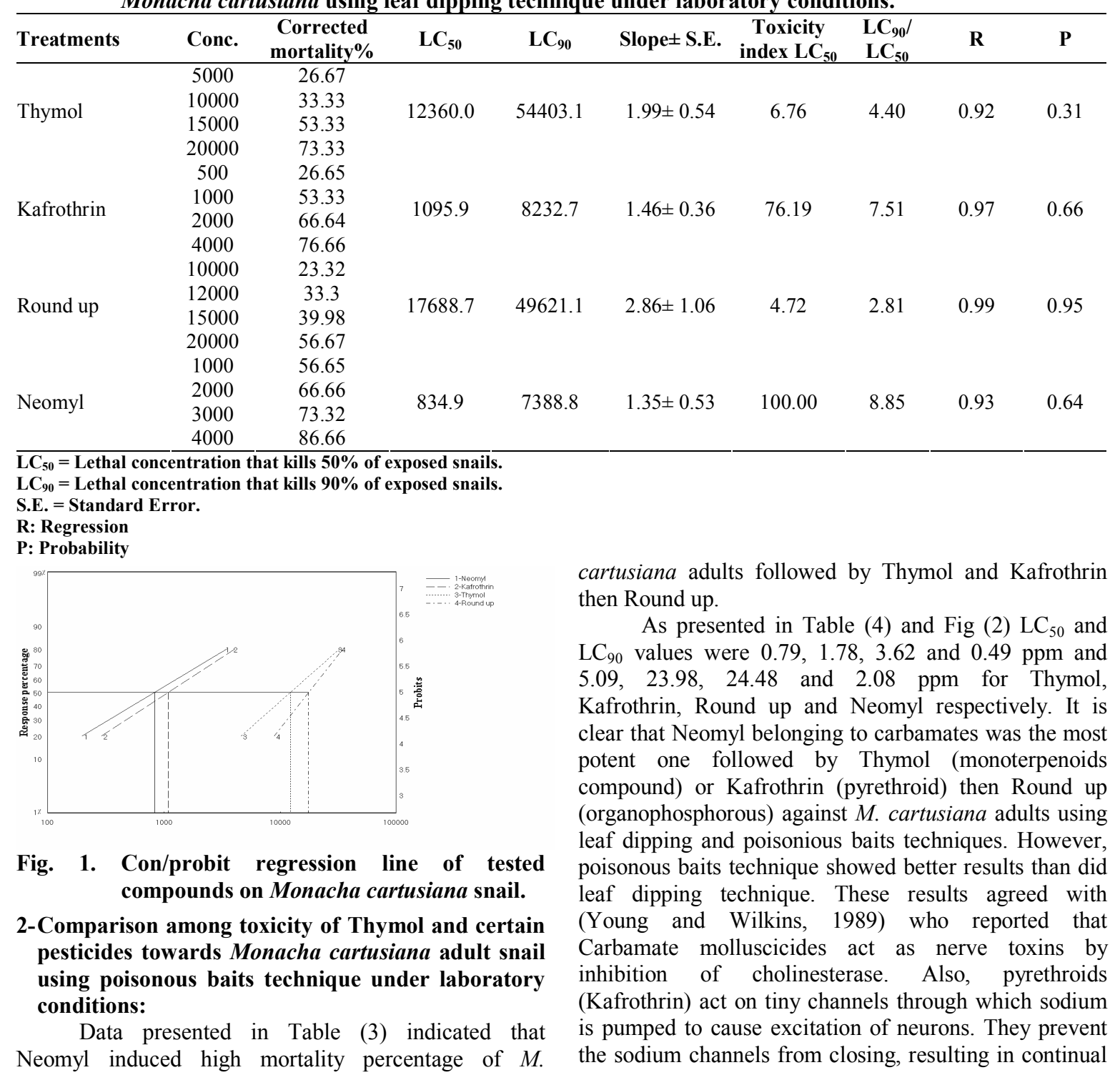


nerve impulse transmission, tremors, and eventually, death (Brown, 2006). Also, these results are in agreement with those reported by Aioub et al., (2000) who revealed that carbamate compounds appeared to the most highly toxic while organophosphorous was the least toxic ants under laboratory conditions. Also, Genena and Mostafa (2008) found that deltamethrin (Kafrothrin) belonging to pyrethroid group showed high initial toxicity of $70.0 \%$ against $M$. cantiana after three days of exposure. However, methomyl belonging to carbamate group gave $100.0 \%$ mortality after seven and 12 days for $M$. cantiana. El-Zemity and Radwan (2001) showed that, the molluscicidal activity of major constituents of some essential oils including thymol and other monoterpenoids i.e. carveol, eugenol exhibited high molluscicidal activity against $T$. pisana and $H$. aspersa snails. Also, Beltagi, et al (2010) found that Thymol was the most promising compound, showing molluscicidal activity $\left(\mathrm{LD}_{50} 551.20 \mu \mathrm{g} /\right.$ snail $)$ against the brown garden snail, Eobania vermiculata using the topical application method. Godan (1983) mentioned that herbicides not only kill weeds but also molluscs either through the animal skin or by ingestion through the intestine.

Table 3. Mortality percentages of Monacha cartusiana adult snails after the exposure to different concentrations of Thymol and three pesticides using poisonous baits technique under laboratory conditions.

\begin{tabular}{|c|c|c|c|c|c|c|}
\hline \multirow[b]{2}{*}{ Treatments } & \multirow[b]{2}{*}{$\begin{array}{c}\text { Conc. } \\
(\%)\end{array}$} & \multicolumn{4}{|c|}{ Mortality after treatments \% } & \multirow{2}{*}{$\begin{array}{c}\text { Total } \\
\text { Mortality } \\
\% \\
\end{array}$} \\
\hline & & $\begin{array}{l}\text { One } \\
\text { day }\end{array}$ & $\begin{array}{c}\text { Three } \\
\text { days }\end{array}$ & $\begin{array}{l}\text { Five } \\
\text { days }\end{array}$ & $\begin{array}{c}\text { Seven } \\
\text { days }\end{array}$ & \\
\hline \multirow{3}{*}{ Thymol } & 1 & 0.00 & 13.33 & 20.00 & 26.67 & 60.00 \\
\hline & 2 & 16.67 & 23.32 & 26.67 & 0.00 & 66.66 \\
\hline & 4 & 20.00 & 33.33 & 0.00 & 36.60 & 89.93 \\
\hline \multirow{3}{*}{ Kafrothrin } & 1 & 10.00 & 13.33 & 6.66 & 10.00 & 39.99 \\
\hline & 2 & 13.33 & 16.67 & 16.67 & 3.33 & 50.00 \\
\hline & 4 & 16.66 & 20.00 & 30.00 & 0.00 & 66.66 \\
\hline \multirow{3}{*}{ Round up } & 1 & 3.33 & 10.00 & 0.00 & 6.67 & 20.00 \\
\hline & 2 & 6.67 & 3.33 & 10.00 & 13.30 & 33.30 \\
\hline & 4 & 10.00 & 16.66 & 20.00 & 6.67 & 53.33 \\
\hline \multirow{3}{*}{ Neomyl } & 1 & 13.33 & 13.33 & 16.67 & 30.00 & 73.33 \\
\hline & 2 & 13.33 & 26.66 & 33.33 & 16.67 & 89.99 \\
\hline & 4 & 33.33 & 43.33 & 0.00 & 20.00 & 96.66 \\
\hline
\end{tabular}

Table 4. Molluscicidal activity $\left(\mathrm{LC}_{50}\right.$ and $\left.\mathrm{LC}_{90}\right)$ of $\mathrm{Thymol}$ and three pesticides against the glassy clover snail Monacha cartusiana using poisonous baits technique under laboratory conditions.

\begin{tabular}{|c|c|c|c|c|c|c|c|c|c|}
\hline Treatments & Conc. & $\begin{array}{c}\text { Corrected } \\
\text { mortality } \%\end{array}$ & $\mathbf{L C}_{\mathbf{5 0}}$ & $\mathbf{L C}_{90}$ & Slope \pm S.E. & Toxicity index $\mathrm{LC}_{50}$ & $\mathbf{L C}_{90} / \mathbf{L C}_{50}$ & $\mathbf{R}$ & $\mathbf{P}$ \\
\hline & 1 & 60.00 & & & & & & & \\
\hline \multirow[t]{3}{*}{ Thymol } & 2 & 66.66 & 0.79 & 5.09 & $1.59 \pm 0.61$ & 61.61 & 6.38 & 0.94 & 0.27 \\
\hline & 4 & 89.93 & & & & & & & \\
\hline & 1 & 39.99 & & & & & & & \\
\hline \multirow[t]{3}{*}{ Kafrothrin } & 2 & 50.00 & 1.78 & 23.98 & $1.13 \pm 0.55$ & 27.63 & 13.50 & 0.99 & 0.75 \\
\hline & 4 & 66.66 & & & & & & & \\
\hline & 1 & 20.00 & & & & & & & \\
\hline \multirow[t]{3}{*}{ Round up } & 2 & 33.30 & 3.62 & 24.48 & $1.54 \pm 0.58$ & 13.58 & 6.77 & 0.99 & 0.86 \\
\hline & 4 & 53.33 & & & & & & & \\
\hline & 1 & 73.33 & & & & & & & \\
\hline \multirow[t]{2}{*}{ Neomyl } & 2 & 89.99 & 0.49 & 2.08 & $2.05 \pm 0.80$ & 100.00 & 4.23 & 0.998 & 0.89 \\
\hline & 4 & 96.66 & & & & & & & \\
\hline
\end{tabular}

$\mathbf{L C}_{50}=$ Lethal concentration that kills $50 \%$ of exposed snails. LC $_{90}=$ Lethal concentration that kills $90 \%$ of exposed snails. S.E. = Standard Error.

R: Regression

P: Probability

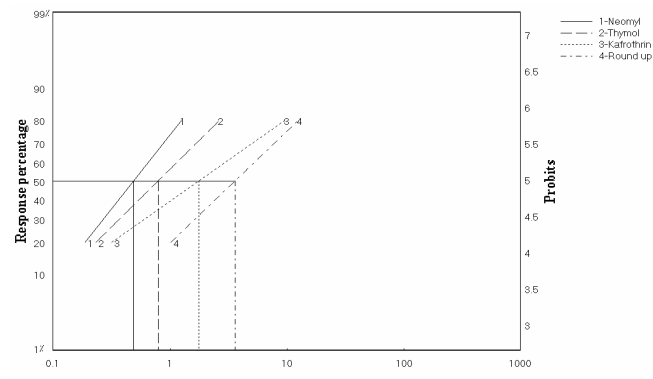

Fig. 2. Con/probit regression line of tested compounds on Monacha cartusiana snail.

Effect of Thymol and three pesticides on egg hatchability of Monacha cartusiana:

The hatchability of $M$. cartusiana eggs treated with Thymol, Kafrothrin, Round up and Neomyl is shown in Table (5). Results showed that Neomyl (1.0) recorded the highest mean reduction in number of hatched eggs followed by Thymol (1.8) and Kafrothrin (3.0) then Round up (4.4) compared to control (18.0).
Similar trend was noticed with rate of hatchability with values of $0.06,0.10,0.17$ and 0.24 for Neomyl, Thymol, Kafrothrin and Round up respectively. El- Massry (1997) found that all concentrations of the tested pesticides i.e methamidophos. malathion and chloropyrifos methyl significantly decreased the percentages of eggs hatchability of Helicella vestalis snails. Ferreira et al. (2011) found that Thymol had ovicidal activity (98\%) against Subulina octona eggs. However, eggs treated with Thymol at 5 and $2.5 \mathrm{~g} / \mathrm{L}$ did not hatch. Hence, Thymol could also be used to control the snails by inactivating their eggs, since these animals have a large reproductive capacity and some of the products in use manage to affect the snail, but not their eggs. Shoaib et al. (2009) found that $\mathrm{LC}_{50}$ of Nimbecidine ${ }^{\circledR}$ ( containing azadirachtin $0.03 \%$ ) for the treated eggs was $2.18 \mathrm{ml} / \mathrm{L}$ and eggs failed to hatch at concentration of $10 \mathrm{ml} / \mathrm{L}$, which caused $100 \%$ mortality of eggs. From the previous results we can concluded that Neomyl was the most effective one on egg hatchability of $M$. cartusiana followed by Thymol and Kafrothrin then Round up which recorded the lowest effective one. 
Table 5. Effect of Thymol and three pesticides on egg hatchability of the glassy clover snail, Monacha cartusiana

\begin{tabular}{lcccc}
\hline Treatments $\begin{array}{c}\text { Aver. no. of } \\
\text { exposed } \\
\text { eggs }\end{array}$ & $\begin{array}{c}\text { Aver. no. } \\
\text { of hatched } \\
\text { eggs }\end{array}$ & $\begin{array}{c}\text { Rate of } \\
\text { hatchability }\end{array}$ & $\begin{array}{c}\text { Egg } \\
\text { hatchability } \\
\text { ( mean } \pm \text { SE) }\end{array}$ \\
\hline Thymol & 20 & 1.8 & 0.10 & $1.8 \pm 0.80^{\mathrm{bc}}$ \\
Kafrothrin & 20 & 3.0 & 0.17 & $3.0 \pm 1.38^{\mathrm{bc}}$ \\
Round up & 20 & 4.4 & 0.24 & $4.4 \pm 1.57^{\mathrm{b}}$ \\
Neomyl & 20 & 1.0 & 0.06 & $1.0 \pm 0.55^{\mathrm{c}}$ \\
Control & 20 & 18.0 & 1.00 & $18.0 \pm 0.95^{\mathrm{a}}$ \\
\hline Each value represented mean of five replicates. \\
No. of hatched eggs (treated group) \\
Rate of hatchability = No. of hatched eggs (control group) \\
S.E. = Standard Error.
\end{tabular}

Effect of Thymol and three pesticides on the incubation period of Monacha cartusiana eggs:

Results in Table (6) clearly indicated that incubation period $M$. cartusiana eggs treated with Thymol, Kafrothrin, Round up and Neomyl ranged between 21 and 26; 19 and 27 days; 19 and 25 days and 23 and 27 days respectively. Also, data proceeded that Neomyl was the most effective one on the incubation period of $M$. cartusiana eggs (25 days in average) followed by Thymol (23.5 days in average), Kafrothrin (23 days in average) and Round up (22 days in average) compared to control (20 days in average).

Table 6. Effect of Thymol and three pesticides on the incubation period of Monacha cartusiana eggs.

\begin{tabular}{|c|c|c|c|c|c|c|c|c|c|c|c|c|c|c|}
\hline \multirow{2}{*}{ Treatments } & \multicolumn{11}{|c|}{ Aver. No. of hatched eggs after ........ (days) } & \multicolumn{2}{|c|}{ Range (in days) } & \multirow{2}{*}{ Mean } \\
\hline & 17 & 18 & 19 & 20 & 21 & 22 & 23 & 24 & 25 & 26 & 27days & Min & Max & \\
\hline Thymol & - & - & - & - & 0.4 & 0.4 & 1.2 & 1.2 & 1.4 & 1.8 & 1.8 & 21 & 26 & 23.5 \\
\hline Kafrothrin & - & - & 0.2 & 0.4 & 0.6 & 1.2 & 1.4 & 2.0 & 2.0 & 2.6 & 3.0 & 19 & 27 & 23 \\
\hline Round up & - & - & 0.2 & 0.2 & 0.6 & 8.0 & 1.6 & 3.4 & 4.4 & 4.4 & 4.4 & 19 & 25 & 22 \\
\hline Neomyl & - & - & - & - & - & - & 0.2 & 0.4 & 0.4 & 0.6 & 1.0 & 23 & 27 & 25 \\
\hline Control & 3 & 5 & 8 & 10 & 13 & 14 & 18 & 18 & 18 & 18 & 18 & 17 & 23 & 20 \\
\hline
\end{tabular}

Each value represented mean of five replicates.

Efficiency of Thymol comparing with three pesticides used as poisonous baits against the glassy clover snail Monacha cartusiana infesting Egyptian clover under field conditions:

Data presented in Table (7) showed the reduction percentage values of $M$. cartusiana snail exposed to Thymol, Kafrothrin, Round up and Neomyl using poisonous baits technique. Data showed that the percentages of snail's reduction after the first three days of treatment were 52.32, 45.13, 18.94 and $66.86 \%$ for Thymol, Kafrothrin, Round up and Neomyl, respectively. The residual effects of these compounds were $59.31,54.93,15.45$ and $78.35 \%$ reduction, consequently with averages of $55.82,50.03,17.20$ and

Table 7. Reduction percentage of Monacha cartusiana snails infesting Egyptian clover following the addition of Thymol and three pesticides under field condition at Dakahlia Governorate.

\begin{tabular}{lcccccccc}
\hline Treatments & \multicolumn{4}{c}{ Reduction percentage after indicated days (\%) } & \multicolumn{2}{c}{ Mean of } \\
& $\mathbf{1}$ & $\mathbf{3}$ & Initial & kill & $\mathbf{7}$ & $\mathbf{1 4}$ & $\mathbf{2 1}$ & Residual \\
effect & reduction \%o \\
\hline Thymol & 49.28 & 55.36 & 52.32 & 57.84 & 59.43 & 60.65 & 59.31 & 55,82 \\
Kafrothrin & 44.10 & 46.15 & 45.13 & 53.51 & 54.26 & 57.01 & 54.93 & 50.03 \\
Round up & 21.20 & 16.67 & 18.94 & 20.83 & 15.79 & 9.72 & 15.45 & 17.20 \\
Neomyl & 62.19 & 71.53 & 66.86 & 76.71 & 78.26 & 80.07 & 78.35 \\
\hline
\end{tabular}

Initial kill $=$ Mean percentage of reduction during the first and third days.

Residual effect $=$ Mean percentage of reduction during the rest periods.

\section{REFERENCES}

Abbott, W.S. (1925): A method of computing the effectiveness of an insecticide. J.Econ. Entomol., 18: 265-267.

Aioub, A. A.; Sh. A.A. Ismail and A.A. Mohamdein (2000): Toxicological and histological studies on some pesticides-treated land snails. Proceeding of the first International Con. on Biological Science Faculty of Science Tanta Univ., 1 (2): 19:38

Barker, G.M. (2002): Molluscs as crop pests, $1^{\text {st }}$ edition, CAB International

Beltagi, S. M.; S. M. Al-Shinnawy; N. R. Elkattan and H. Nady (2010): Effects of sublethal doses of selected botanical molluscicides on oxygen consumption of the brown garden snail, Eobania vermiculata. Egyp. J. Hosp. Med., 40: 402- 410.

Brown, A.E. (2006): Mode of action of structure pest control chemicals. Pesticide Information Leaflet, 41: $1-8$.
$72.61 \%$ reduction for Thymol, Kafrothrin, Round up and Neomyl, respectively. The most effective one was Neomyl followed by Thymol and Kafrothrin then Round up. The current data agreed with Ismail et al. (2005) who mentioned that methomyl (Neomyl) showed the highest residual effect against $M$. cartusiana snails under field conditions. Samy et al. (2015) reported that Neomyl was the most potent compound in reducing the population density of Monacha spp. in lettuce and cabbage fields. Ismail et al. (2015) reported that poisonous baits technique was more effective than spray technique in controlling $M$. cartusiana snail under field conditions
El-Deeb, H. I.; Z. H. Zidan and M. M. Fouad (2003) Survey of terrestrial snails and their malacophagous insects at three governorates in Egypt. Egyp. Jour. Appl. Sci. 18: 355-361.

El- Massry, S.A. (1997): Studies on control of some land snails infesting certain fruit trees. Ph.D. Thesis, Fac. Of Agric., Zagazig Univ., 150 pp.

El-Okda, M.M. (1981): Response of two land molluscs to certain insecticides. Bull. Ent. Soc. Egypt Econ. Ser., 12: 53-57.

El-Zemity, S. R. and M. A. Radwan (2001): Molluscicidal and antifeedant activity of some essential oils and their major chemical constituents against Theba pisana snails. Arab Univ. J. Agric. Sci. Ain Shams Univ. Cairo, 9(1):483 - 493.

Ferreira, P. A.; L. G. S. Geraldo; Sthefane D'ávila and E. C. Bessa (2011): The influence of caffeine and thymol on the survival, growth and reproduction of Subulina octona (Brugüière, 1789) (Mollusca, Subulinidae). Brazilian. Arc. Bio. Techno., 52 (4): 945-952. 
Finney, D. J. (1971): Probit analysis. Cambridge univ., London pp. 333.

Genena, Marwa A. M. and Fatma A. M. Mostafa (2008): Molluscicidal activity of six pesticides against the two land snails, Monacha cantiana and Eobania vermiculata (Gastropoda: Helicidae) under laboratory conditions. J. Agric. Sci. Mansoura Univ., 33: 5307-5315.

Ghamry, E. M. (1994): Local cruciferous seeds having toxic effect against certain land snails under laboratory conditions. Egypt, J. App. Sci., 9 (3): 632-640.

Godan, D., (1983): Pest slugs and snails, biology and control, Springer Verlag, Berlin.

Henderson, G. F. and Tilton, E. W. (1955): Test with acaricides against the brown wheat mite. J. Econ. Entomol., 48: 157- 161.

Iglesias, J.; J. Castillejo and R.Castro (2003): The effects of repeated applications of the molluscicide metaldehyde and the biocontrol nematode Phasmarhabditis hermaphrodita on mollusks, earth worms, nematodes, acarids and collembolans: a twoyear study in north-west Spain. Pest Manag. Sci., 59: $1217-24$.

Ismail, Sh.A . A; A. A. Abd- Allah; S. A. El- Masry, and A. M.Hegab, (2005): valuation of certain chemiclas and insecticides against Monach cartusiana snails infesting some vegetable crops at Skarkia Gvoernorate, J. Agric. Sci. Mansoura Univ., 30 (10): 6283- 6291.

Ismail, Sh. A. A.; S. Z. Shetaia, and M. M. Khattab (2015): Time of application as main factor affecting the efficacy of certain pesticides against land snail Monacha cartusiana under filed conditions at Sharkia governorate. J. Plant Prot. And Path., Mansoura. Univ., 5:(6):

Kumar, S.; N. Wahab; M. Mishra and R.Warikoo, (2012): Evaluation of 15 local plant species as larvicidal agents against an Indian strain of Dengue fever mosquito, Aedes aegypti L. (Diptera: Culicidae). Frontiers in Physiology, 3:104
Powell, A. and L.D. Bowen (1996): The screening of naturally occurring compounds for use as seed treatment for the protection of winter wheat against slug damage. In slug and snail pests in agriculture (ed. By Henderson, I.F.), British Crop Protection Council, BCPC Monograph 66: 231-236.

Rice, P.J. and J.R. Coats (1994): Insecticidal properties of several monoterpenoids to the house fly ( Diptera: Muscidae), red flour beetle (Coleoptera: Tencbrionidea) and Southern corn rootworm (Coleoptera: Chrysomelidae) J. Ecom.Entomol., 87 (5): 1172- 1179.

Samy, M. A.; SK. M. Fakharany, and A. S. Hendawy (2015): Population fluctuation and host preference of land snail, Monacha spp and its control of biocides compared with neomyl. Fifth Intern. Comp. Plant Prot. Res. Inst. Hurgada. Egypt 3-9 May 2015. Sustainable Agricultural Development the Agricultural Production and the Challenges of Plant Protections.

Shoaib, M.A.; F.M. Mahmoud; N. Loutfy; M.A. Tawfic and M. Barta (2009): Effect of botanical insecticide Nembecidine ${ }^{\circledR}$ on food consumption and egg hatchability of terrestrial snail Monacha obstructa. J. Pest. Sci., Accepted 30 June 2009. Springer-Verlag 2009.

Speiser, B and C. Kistler (2002): Field tests with a molluscicide containing iron phosphate. Crop Protection, 21: 389-94.

Sun,Y.P. (1950): Toxicity index an improved method of comparing the relative toxicity of insecticides. J. Econ. Entomol., 43 : 45-53.

Wicht, M. J.; R. Haak; H. Schütt-Gerowitt; S. M.J. Kneist and Noack, (2004), Suppression of caries-related microorganisms in dentine lesions after short-term chlorhexidine or antibiotic treatment. Caries Res. 38: 436-441.

Young, A.G. and Wilkins, RM (1989): A new technique for accessing the contact toxicity of molluscicides to slugs. Journals of Molluscan Studies 53:533-536.

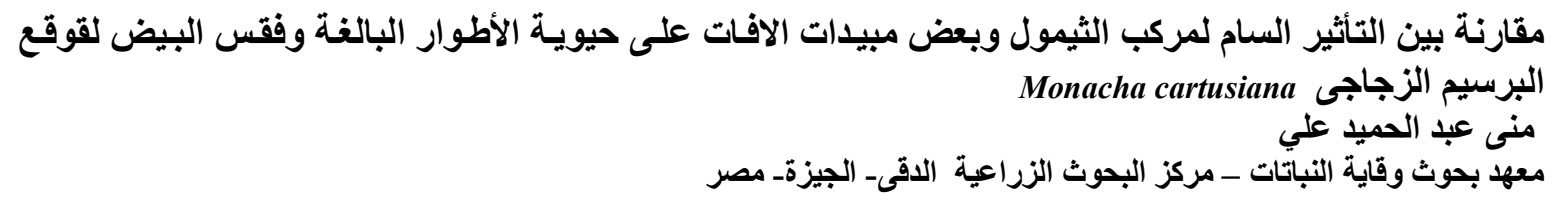

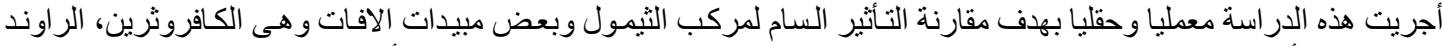

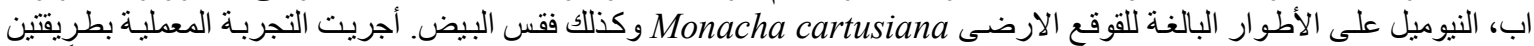

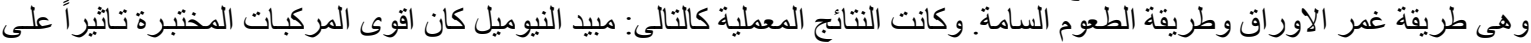

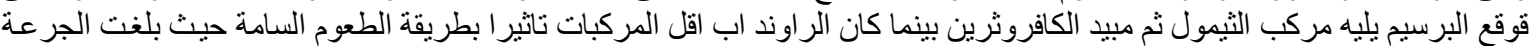

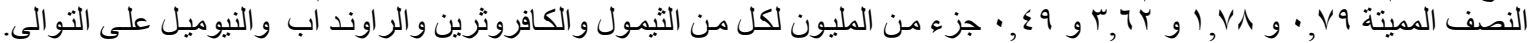

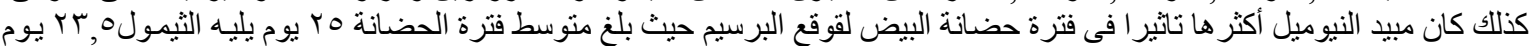

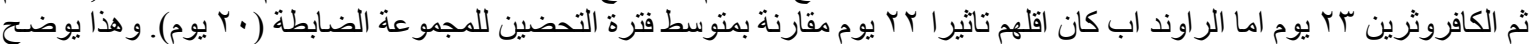

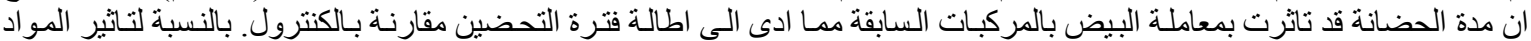

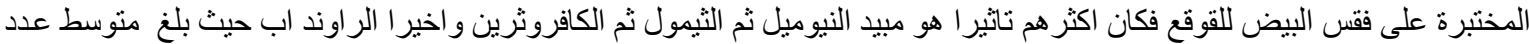

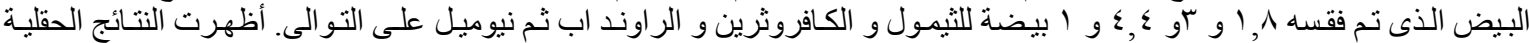

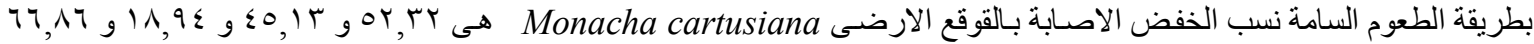

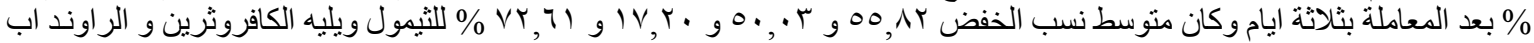

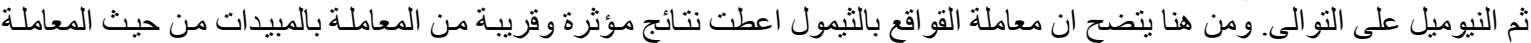

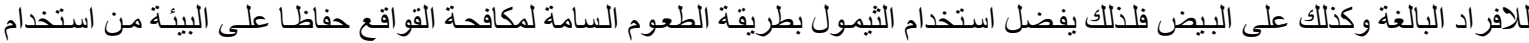

